\section{Pelaksanaan Dental Health Education (DHE) dalam meningkatkan status kebersihan gigi dan mulut pada murid SDN 33 Kota Banda Aceh Implementation of Dental Health Education (DHE) in improving the status of dental and oral hygiene in pupils of primary school 33st in Banda Aceh}

SAGO: Gizi dan Kesehatan 2020, Vol. 1(2) 128-133 (C) The Author(s) 2020

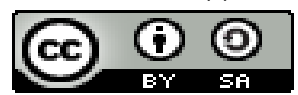

DOI: http://dx.doi.org/10.30867/sago.v1i1.404 https://ejournal.poltekkesaceh.ac.id/index.php/ gikes

Poltekkes Kemenkes Aceh

\author{
Reca $^{1}$, Ainun Mardhiah ${ }^{2}$, dan Cut Aja Nuraskin ${ }^{3}$
}

\begin{abstract}
Background: Dental and oral health is one part that can not be separated from overall body health. Dental and oral care as a whole begins with dental and oral hygiene for each individual. Teaching methods of brushing teeth for children need to be given examples of a good model and with the simplest technique possible.

Objectives: The research aims to increase the knowledge of SDN 33 Banda Aceh City students in maintaining dental and oral health and improve the dental and oral hygiene status of SDN 33 Banda Aceh City students.

Method: The research using a quantitative method with a descriptive approach, with the target of Class $V$ students of SDN 33 Banda Aceh City Banda Aceh City totaling 30 children. Data analysis uses univariate analysis. The interventions provided were in the form of Dental Health Education (DHE).

Results: The results of these community service activities show there is an increase in students' knowledge in the maintenance of dental and oral hygiene in SDN 33 Banda Aceh City students, with an increase before the intervention (pre-test) is in the sufficient category (56.7\%) and after the intervention (post test) in the good category (96.7\%). There was an increase in the status of dental and oral hygiene of students, with an increase before the intervention (pre-test) was in the bad category (100\%) and after the intervention (post test) was in the good category (100\%).

Conclusion: It is recommended that schools provide regular counseling to students about the importance of maintaining oral health and holding joint toothbrushes to improve oral and dental hygiene.
\end{abstract}

\title{
Keywords
}

Dental Health Education, dental hygiene, elementary school students, knowledge

\begin{abstract}
Abstrak
Latar Belakang: Kesehatan gigi dan mulut merupakan salah satu bagian yang tidak dapat dipisahkan dari kesehatan tubuh secara keseluruhan. Perawatan gigi dan mulut secara keseluruhan diawali dari kebersihan gigi dan mulut pada setiap individu. Pendidikan cara-cara penyikatan gigi bagi anak-anak perlu diberikan contoh suatu model yang baik serta dengan teknik yang sesederhana mungkin.

Tujuan: Penelitian ini bertujuan untuk meningkatkan pengetahuan murid SDN 33 Kota Banda Aceh dalam pemeliharaan kesehatan gigi dan mulut dan meningkatkan status kebersihan gigi dan mulut murid SDN 33 Kota Banda Aceh.

Metode: Penelitian ini dilakukan dengan metode kuantitatif dengan pendekatan deskriptif, dengan sasaran yaitu murid Kelas V SDN 33 Kota Banda Aceh Kota Banda Aceh yang berjumlah 30 anak. Analisis data menggunakan analisis univariat. Intervensi yang diberikan berupa Dental Health Education (DHE).
\end{abstract}

\footnotetext{
1 Jurusan Keperawatan Gigi Politeknik Kesehatan Kemenkes Aceh, Aceh, Indonesia. E-mail: reca.zulkarnain@yahoo.com

2 Jurusan Keperawatan Gigi Politeknik Kesehatan Kemenkes Aceh, Aceh, Indonesia. E-mail: ainun_mardiah_66@yahoo.com

3 Jurusan Keperawatan Gigi Politeknik Kesehatan Kemenkes Aceh, Aceh, Indonesia. E-mail: cutaja82@yahoo.co.id
} 
Hasil: Hasil menunjukkan ada peningkatan pengetahuan murid dalam pemeliharaan kebersihan gigi dan mulut pada murid SDN 33 Kota Banda Aceh, dengan peningkatan sebelum intervensi (pre-test) berada pada kategori cukup (56,7\%) dan setelah intervensi (post test) berada pada kategori baik (96,7\%). Ada peningkatan Status Kebersihan gigi dan mulut murid, dengan peningkatan sebelum intervensi (pre-test) berada pada kategori buruk (100\%) dan setelah intervensi (post test) berada pada kategori baik (100\%).

Kesimpulan: Pihak sekolah perlu melakukan penyuluhan kepada murid secara rutin tentang pentingnya pemeliharaan kesehatan gigi dan mulut dan mengadakan sikat gigi bersama untuk meningkatkan kebersihan gigi dan mulut

\section{Kata Kunci}

Dental Health Education, murid SD, pengetahuan, status kebersihan gigi

\section{Pendahuluan}

K esehatan gigi dan mulut merupakan salah satu bagian yang tidak dapat dipisahkan dari kesehatan tubuh secara keseluruhan. Perawatan gigi dan mulut secara keseluruhan diawali dari kebersihan gigi dan mulut pada setiap individu. Selain itu gigi geligi merupakan salah satu organ pencernaan yang berperan penting dalam proses pengunyahan makanan, sehingga pemeliharaan kesehatan gigi penting dilakukan (Kemenkes RI, 2012). Upaya pemeliharaan kesehatan gigi dan mulut sebaiknya dilakukan sejak usia dini. Usia sekolah dasar merupakan saat yang ideal untuk melatih kemampuan motorik seorang anak, termasuk diantaranya menyikat gigi. Kemampuan menyikat gigi secara baik dan benar merupakan faktor yang cukup penting untuk pemeliharaan kesehatan gigi dan mulut. Keberhasilan pemeliharaan kesehatan gigi dan mulut juga dipengaruhi oleh faktor penggunaan sikat gigi, metode penyikatan gigi, serta frekuensi dan waktu penyikatan yang tepat (Darwita et al., 2011).

Hasil Riset Kesehatan Dasar tahun 2013 menunjukkan penduduk Indonesia yang mempunyai masalah gigi dan mulut sebesar $25.9 \%$. Tercatat $62.9 \%$ penduduk di provinsi Aceh mengalami karies, dan umumnya masyarakat menggosok gigi setiap harinya pada waktu mandi pagi dan mandi sore sebanyak $90.7 \%$, sementara proporsi masyarakat yang menggosok gigi setiap hari sesudah makan pagi hanya $12,6 \%$ dan sebelum tidur hanya 20.7\% (Kemenkes RI, 2013). Berdasarkan laporan Dinas Kesehatan Kota Banda Aceh pada tahun 2014, penyakit gigi dan mulut (karies) menduduki urutan ke 14 dari 20 penyakit terbesar dengan kunjungan 4779 kunjungan. Menurut hasil pemeriksaan gigi dan mulut kelompok umur 6-14 tahun di Kota Banda Aceh pada kegiatan UKGS menunjukkan bahwa 34\% anak menderita karies (Dinkes Aceh, 2018). Keadaan kesehatan gigi dan mulut di wilayah Kota Banda Aceh menunjukkan bahwa status kesehatan gigi dan mulut masih memprihatinkan.

Kerusakan gigi yang umumnya terjadi pada usia dini (anak-anak) biasanya karena faktor makanan/minuman yang manis. Hal ini sesuai dengan seorang peneliti epidemiologis yang berpendapat bahwa anak-anak cenderung lebih menyukai makanan manis seperti coklat dan permen yang dapat menyebabkan karies. Anakanak sangatlah sulit menghindari makanan tersebut karena banyaknya bahan makanan yang ditambah kadar gulanya. Mereka lebih menyukai makanan manis dan melekat yang biasanya menjadi hidangan sehari-hari di rumah dan di sekolah. Pada umumnya makanan tersebut dipakai sebagai makanan selingan antara waktu makan dan didukung dengan ketidaktahuan anak tentang kesehatan gigi yang dapat mempengaruhi status kesehatan gigi anak (Karmawati et al., 2012).

Masalah karies tidak dapat dibiarkan dan kecenderungan peningkatannya di masa mendatang tidak dicegah, akibatnya akan sangat merugikan. Dampak karies bagi anak-anak sangat besar, antara lain: rasa sakit, gangguan fungsi kunyah yang menghambat konsumsi makanan atau nutrisi, anemia, gangguan kenyamanan berupa kurang tidur dan berujung pada menurunnya kualitas hidup anak tersebut. Dampak lainnya adalah gangguan konsentrasi belajar yang akan berpengaruh pada prestasi belajar. Masalah gigi memang tidak masuk dalam daftar penyakit mematikan. Kondisi inilah yang membuat sebagian masyarakat mengesampingkan upaya mencegah bahkan juga mengobati penyakit gigi dan mulut (Nubatonis, 2019).

Salah satu indikator kesehatan gigi dan mulut adalah tingkat kebersihan gigi dan mulut. Hal tersebut dapat dilihat secara klinis dari ada tidaknya deposit-deposit organik, seperti pelikel, materia alba, debris, kalkulus, dan plak gigi. Plak merupakan deposit lunak yang membentuk lapisan biofilm dan 
melekat pada permukaan gigi dan gusi serta permukaan jaringan keras lainnya dalam rongga mulut. Kebersihan gigi dan mulut merupakan suatu tindakan untuk membersihkan gigi dan gusi untuk mencegah penyakit gigi dan mulut (Priyanto, 2011).

Mengingat risiko yang terjadi pada karies berpengaruh terhadap proses tumbuh kembang anak, maka cara pencegahan yang lebih awal penting untuk dilakukan. Perawatan gigi dan mulut sejak usia dini sangat menentukan kesehatan gigi dan mulut sampai akhir hayat (Newman et al., 2011). Pencegahan dapat dilakukan dengan cara membiasakan anak menggosok gigi minimal 2 kali sehari selama kurang lebih 2 (dua) menit sesudah makan dan sebelum tidur serta gunakan kain kassa basah untuk membersihkan gigi, gusi dan lidah. Mengurangi/membatasi anak makan-makanan yang mengandung gula atau yang mudah menempel pada permukaan gigi seperti permen, coklat dan lain-lain. Perkenalkan anak-anak untuk makan-makanan atau buah-buahan yang berserat dan berair seperti pepaya, jeruk, semangka, jambu air dan lain-lain yang dapat membantu membersihkan gigi. Perkenalkan dan ajarkan kepada anak minum dengan cup (gelas) saat mulai menginjak usia 2 tahun. Konsultasilah dengan tenaga kesehatan gigi akan kebutuhan fluor pada gigi anak dan melakukan pemeriksaan secara rutin ke klinik gigi (Priyanto, 2011). Oleh karena itu dibutuhkan gagasan inovatif sehingga tenaga kesehatan gigi dapat mengembangkan suatu model promosi kesehatan dan pencegahan karies melalui pengendalian faktor risiko karies, salah satunya melalui penyuluhan dan pelatihan cara sikat gigi yang benar (dental health education). Dental health education ini dapat mengajarkan dan mendidik anak melakukan kebiasaan pemeliharaan Kesehatan gigi sejak dini yang dapat mempengaruhi kesehatan gigi dan mulut di kemudian hari (Newman et al., 2011).

Pendidikan cara-cara penyikatan gigi bagi anak-anak perlu diberikan contoh suatu model yang baik serta dengan teknik yang sesederhana mungkin. Penyampaian pendidikan kesehatan gigi dan mulut pada anak-anak harus dibuat semenarik mungkin, antara lain melalui penyuluhan yang atraktif tanpa mengurangi isi pendidikan, demonstrasi secara langsung, program audio visual, atau melalui sikat gigi massal yang terkontrol (Darwita et al., 2011).

Masa anak merupakan awal dari pembentukan perilaku. Pada masa tersebut anak paling rentan terhadap berbagai pengaruh, baik yang datang dari dalam maupun dari luar diri sang anak. Tidak mengherankan apabila anak-anak cukup rentan mengalami perubahan status kesehatan, termasuk di dalamnya karies. Anak usia antara 10-12 tahun, merupakan usia yang dianjurkan WHO untuk dilakukan penelitian kesehatan gigi dan mulut. Pada kelompok usia ini minat belajar anak tinggi didukung oleh ingatan anak yang kuat sekali serta kemampuan dalam menangkap dan memahami materi yang diberikan (Nurasiki \& Amiruddin, 2017).

Selain itu, pada tingkat ini anak mudah dididik dan senang berada di sekitar orang-orang yang memberi perhatian padanya. Secara umum, perilaku kesehatan gigi pada usia ini lebih kooperatif daripada kelompok umur yang lebih muda dan ini juga dianggap sudah mandiri dalam kegiatan menyikat gigi. Umur 10-12 tahun juga merupakan periode kritis dalam pengadopsian, pemeliharaan, dan peningkatan gaya hidup anak. Pada tahap ini terjadi peningkatan proses metabolisme yang mengakibatkan kebutuhan energi meningkat. Meningkatnya kebutuhan energi menyebabkan perilaku mengkonsumsi makanan dan mengemil pada anak juga meningkat dan pola makan yang tidak teratur dibandingkan tingkatan usia anak lainnya. Perilaku kebiasaan menyikat gigi yang baik dan perilaku mengkonsumsi makanan yang baik tentunya sangat tepat diajarkan pada usia tersebut mengingat terjadinya peningkatan frekuensi makan dan pola makan yang tidak teratur (Tinanoff \& Douglass, 2001).

\section{Metode}

Desain yang digunakan yaitu dengan pendekatan kuasi eksperimen dan dilakukan secara pre dan pos tes. Penelitian dilaksanakan di SDN 33 Kota Banda Aceh yaitu pada bulan Mei 2018, dengan sampel sebanyak 30 murid.

Pengumpulan data meliputi variabel karakteristik, kebersihan gigi dan mulut, serta pengetahuan mutid SD. Metode pengumpulan data dengan menggunakan ceramah, tanya jawab, demostrasi, diskusi, simulasi (pelatihan cara menyikat gigi yang benar).

Data yang telah dikumpulkan selanjutnya diolah secara komputerisasi melewati tahapan editing, koding, entry dan tabulating. 
Pengolahan data didasarkan pada masingmasing variabel. Analisis statistik yang digunakan yaitu secara univariat. Uji statistik univariat dalam penelitian ini yaitu menggunakan uji distribusi frekuensi.

\section{Hasil}

Hasil penelitian yang telah dilkukan pada murid SDN 33 Kota Banda Aceh secara karakteristik anak dapat dideskripsikan sebagai berikut:

Tabel 1. Distribusi frekuensi karakteristik anak

\begin{tabular}{lcc}
\hline \multicolumn{1}{c}{ Karakteristik Anak } & $\mathrm{n}$ & $\%$ \\
\hline Umur & & \\
11 tahun & 7 & 23.3 \\
12 tahun & 23 & 76.7 \\
Jenis Kelamin & & \\
$\quad$ Laki-laki & 14 & 46.7 \\
$\quad$ Perempuan & 16 & 53.3 \\
\hline
\end{tabular}

Berdasarkan Tabel 1 diatas, menunjukkan bahwa karakteristik anak berdasarkan umur, anak umur 11 tahun (23.3\%) dan anak umur 12 tahun (76.7\%). Berdasarkan jenis kelamin, laki-laki (46.7\%) dan perempuan (53.3\%).

Pengetahuan responden pada tahap sebelum intervensi (pre test) dan sesudah intervesi (post test) selengkapnya dapat dilihat pada tabel 2 yaitu distribusi frekuensi pengetahuan antara sebelum penyuluhan dengan setelah penyuluhan pada SDN 33 Kota Banda Aceh.

Tabel 2. Distribusi frekuensi pengetahuan responden tahap pre test dan post test $(n=30)$

\begin{tabular}{lcccc}
\hline \multirow{2}{*}{ Pengetahuan } & \multicolumn{2}{c}{ Pretes } & \multicolumn{2}{c}{ Postes } \\
\cline { 2 - 5 } & $f$ & $\%$ & $f$ & $\%$ \\
\hline Kurang & 12 & 40 & 0 & 0 \\
Cukup & 17 & 56.7 & 1 & 3.3 \\
Baik & 1 & 3.3 & 29 & 96.7 \\
\hline
\end{tabular}

Tabel 2, menunjukkan bahwa distribusi terbesar pengetahuan responden sebelum intervensi (pre-test) berada pada kategori cukup (56.7\%). Distribusi terbesar pengetahuan responden sesudah intervensi (post test) berada pada kategori baik (96.7\%).

Status kebersihan gigi dan mulut anak pada tahap sebelum intervensi (pre test) dan sesudah intervesi (post test) selengkapnya dapat dilihat pada tabel 3 terkait distribusi Status kebersihan gigi dan mulut anak.

Tabel 3. Distribusi Status kebersihan gigi dan mulut anak

\begin{tabular}{lcccc}
\hline Kebersihan gigi & \multicolumn{2}{c}{ Pretes } & \multicolumn{2}{c}{ Postes } \\
\cline { 2 - 5 } \multicolumn{1}{c}{ dan mulut } & $f$ & $\%$ & $f$ & $\%$ \\
\hline Buruk & 30 & 100.0 & 0 & 0 \\
Sedang & 0 & 0 & 0 & 0 \\
Baik & 0 & 0 & 30 & 100.0 \\
\hline
\end{tabular}

Hasil penelitian sebagaimana telah disajikan pada tabel 3, menunjukkan bahwa distribusi terbesar status kebersihan gigi dan mulut anak sebelum intervensi (pre-test) berada pada kategori buruk (100\%). Distribusi terbesar status kebersihan gigi dan mulut anak sesudah intervensi (post test) berada pada kategori baik (100\%).

\section{Pembahasan}

\section{Pengetahuan Murid}

Berdasarkan hasil pengabdian masyarakat di SDN 33 Kota Banda Aceh menunjukkan bahwa persentase pengetahuan murid sebelum dilakukan penyuluhan yang paling banyak adalah pada kategori cukup berjumlah berjumlah 17 orang (56.7\%).

Hasil tersebut menunjukkan bahwa pengetahuan murid tentang kesehatan gigi dan mulut dengan cara menyikat gigi yang baik benar pada kategori cukup, hal tersebut mengakibatkan anak akan berisiko terhadap penyakit gigi dan mulut (karies) sehingga mengakibatkan keadaan kebersihan gigi dan mulut anak buruk. Hal ini sesuai dengan penelitian yang dilakukan pada murid sekolah dasar di Al Hassa Saudi Arabia, mengungkapkan bahwa murid tidak pernah menerima pengetahuan dan intruksi mengenai kesehatan gigi dan mulut, sehingga murid tidak memahami akan pentinganya menjaga kebersihan gigi dan mulut, keadaan ini adalah prediktor utama terjadinya karies gigi pada anak (Vinay et al., 2011).

Berdasarkan hasil penelitian menunjukkan bahwa persentase pengetahuan murid setelah dilakukan penyuluhan tentang kesehatan gigi dan mulut dengan cara kontrol plak yang benar terbanyak adalah kategori baik berjumlah 29 orang (96.7\%). Terlihat adanya peningkatan pengetahuan murid setelah dilakukan tentang edukasi kesehatan gigi dan mulut dan pelatihan menyikat gigi yang baik 
dan benar. Menurut Kantohe et al. (2016), hal tersebut dapat terjadi dikarenakan penyuluhan telah dapat meningkatkan pengetahuan murid sehingga anak akan dapat mengenali masalah kesehatan gigi dan mulut lebih mudah.

Menggali faktor penyebab dan menjelaskan proses terjadinya masalah gigi sehingga murid memahami, timbul kesadaran, kemauan sehingga termotivasi untuk memelihara kesehatan gigi dan mulutnya (Simaremare \& Simaremare, 2014). Keadaan ini sesuai dengan penelitian yang dilakukan di Bangalor, India, bahwa murid yang mengetahui tentang permasalahan kesehatan gigi dan mulut, dan menanamkan praktik untuk memperhatikan kebersihan gigi, hal tersebut mempengaruhi terhadap kesehatan gigi dan mulut sehingga mereka lebih memperhatikan dan mengontrol untuk menyikat gigi dengan benar dan tepat waktu (Davies et al., 2002).

\section{Status Kebersihan Gigi Dan Mulut Murid}

Berdasarkan hasil penelitian telah diketahui bahwa adanya peningkatan status kebersihan gigi dan mulut anak dari pre test dan post test, persentase status kebersihan gigi dan mulut anak sebelum dilakukan penyuluhan tentang kesehatan gigi dan mulut dengan cara kontrol plak yang benar terbanyak adalah pada kriteria buruk (100\%). Sedangkan persentase status kebersihan gigi dan mulut anak sesudah dilakukan edukasi kesehatan gigi yang paling banyak adalah pada kriteria baik (100\%).

Peningkatan status kebersihan gigi dan mulut anak disebabkan karena murid sudah mengetahui cara memelihara kesehatan gigi dan mulut dalam hal ini murid sudah memahami dan melaksanakan cara menyikat gigi yang baik dan benar serta sudah memahami bahwa kebersihan gigi dan mulut harus dijaga secara rutin dan teratur (Arianto et al., 2014). Dengan kegiatan tersebut diatas, murid lebih memperhatikan kebersihan gigi dan mulutnya dalam menyikat gigi yang teratur sehingga dapat tercegah dari penyakit gigi dan mulut (Hastuti \& Andriyani, 2010). Hal ini sesuai dengan penelitian yang dilakukan pada murid sekolah di Trinidad, bahwa mengunjungi rumah secara rutin memberikan konseling dan wawancara kepada orang tua, memberi penjelasan tentang kebersihan gigi dan mulut anak kepada orang tua, sehingga orang tua merasa gigi anak harus disikat tiga kali sehari secara benar dan teratur (Twetman et al., 2003). Peran murid dalam memelihara kesehatan gigi sangat penting terutama dalam hal menjaga waktu yang tepat menyikat gigi dan teknik menyikat gigi yang benar (Andriani \& Wilis, 2018).

\section{Kesimpulan}

Terdapat peningkatan pengetahuan murid dalam pemeliharaan kebersihan gigi dan mulut pada murid SDN 33 Kota Banda Aceh, dengan peningkatan sebelum intervensi (pre-test) berada pada kategori cukup (56.7\%) dan setelah intervensi (post test) berada pada kategori baik (96.7\%). Ada peningkatan Status Kebersihan gigi dan mulut murid, dengan peningkatan sebelum intervensi (pre-test) berada pada kategori buruk (100\%) dan setelah intervensi (post test) berada pada kategori baik (100\%).

Saran, Perlu adanya penyuluhan kepada murid secara rutin baik dari guru maupun tenaga kesehatan gigi dari Puskesmas tentang pentingnya pemeliharaan kesehatan gigi dan mulut dan mengadakan sikat gigi bersama untuk meningkatkan kebersihan gigi dan mulut. Meningkatkan status kebersihan gigi dan mulut sebaiknya dilakukan penyuluhan dengan melibatkan orang tua murid, guru UKS, dan para guru.

\section{Ucapan Terima Kasih}

Ucapan terimakasih disampaikan kepada Ketua Jurusan Keperawatan Gigi Politeknik Kesehatan Kemenkes Aceh yang telah membantu kontribusi terhadap pelaksanaan penelitian.

Selain itu, ucapan terima kasih juga kami sampaikan kepada Bapak pembimbing/ supervisor yang telah membantu perbaikan baik secara teknis maupun isi dalam pelaksanaan penelitian ini. Kepala SDN 33 Kota Banda Aceh yang telah memberikan kesempatan dan membantu penulis dalam melakukan penelitian, juga para Guru serta para responden.

\section{Daftar Rujukan}

Andriani, A., \& Wilis, R. (2018). Efektifitas mengkomsumsi jus apel dibandingkan dengan mengkonsumsi jus jambu biji terhadap penurunan tingkat halitosis. AcTion: Aceh Nutrition Journal, 3(2), 164-171. https://doi.org/http://dx.doi.org/10.30867/a ction.v3i2.147 
Arianto, A., Shaluhiyah, Z., \& Nugraha, P. (2014). Perilaku Menggosok Gigi pada Siswa Sekolah Dasar Kelas V dan VI di Kecamatan Sumberejo. Jurnal Promosi Kesehatan Indonesia, 9(2), 127-135.

Darwita, R. R., Novrinda, H., Budiharto, P. P. D., Amalia, R., \& Asri, S. R. (2011). Efektivitas Progam Sikat Gigi Bersama Terhadap Risiko Karies Gigi pada Murid Sekolah Dasar. J Indon Med Assoc, 61(5), 204-209.

Davies, G. M., Worthington, H. V, Ellwood, R. P., Bentley, E. M., Blinkhorn, A. S., Taylor, G. O., \& Davies, R. M. (2002). A randomised controlled trial of the effectiveness of providing free fluoride toothpaste from the age of 12 months on reducing caries in 5-6-year-old children. Community Dental Health, 19(3), 131-136.

Dinkes Aceh. (2018). Profil Kesehatan Aceh Tahun 2017.

Hastuti, S., \& Andriyani, A. (2010). Perbedaan Pengaruh Pedidikan Kesehatan Gigi dalam Meningkatkan Pengetahuan tentang Kesehatan Gigi pada Anak di SD Negeri 2 Sambi Kecamatan Sambi Kabupaten Boyolali. Gaster/ Jurnal IImu Kesehatan, 7(2), 624-632.

Kantohe, Z. R., Wowor, V. N. S., \& Gunawan, P. N. (2016). Perbandingan efektivitas pendidikan kesehatan gigi menggunakan media video dan flip chart terhadap peningkatan pengetahuan kesehatan gigi dan mulut anak. E-GiGi, 4(2), 36-42.

Karmawati, I. A., Tauchid, S. N., \& Harahap, N. N. (2012). Perbedaan risiko terjadinya karies baru pada anak usia 12 tahun murid SD UKGS dan SD non UKGS di Wilayah Kecamatan Cilandak Jakarta Selatan tahun 2011. Jurnal Health Quality, 2(4), 223-233.

Kemenkes RI. (2012). Pedoman Usaha Kesehatan Gigi Sekolah (UKGS). Kementerian Kesehatan Republik Indonesia.

Kemenkes RI. (2013). Pokok-pokok hasil Riskesdas Indonesia 2013.
Newman, M. G., Takei, H., Klokkevold, P. R., \& Carranza, F. A. (2011). Carranza's clinical periodontology. Elsevier health sciences.

Nubatonis, M. O. (2019). Faktor Resiko Dan Prediksi Kejadian Karies Gigi Dengan Metode "Irene Donat" Di TK Betlehem Oesapa Barat. Prosiding Semnas Sanitasi, 377-383.

Nurasiki, C. A., \& Amiruddin, A. (2017). Efektifitas Mengunyah Buah Apel dan Buah Bengkoang Terhadap Penurunan Indeks Plak Pada Murid Sekolah Dasar. AcTion: Aceh Nutrition Journal, 2(2), 80-85. https://doi.org/http://dx.doi.org/10.30867/a ction.v2i2.58

Priyanto, I. R. J. H. A. (2011). Perilaku Kesehatan Gigi dan Mulut pada Anak Sekolah Dasar. Berita Kedokteran Masyarakat, 27(4), 180.

Simaremare, R. T., \& Simaremare, A. B. (2014). Motivasi Anak Dalam Pemeliharaan Kesehatan Gigi Terhadap Status Kesehatan Gigi Pada Siswa/I Kelas III-A SD Swasta Cerdas Bangsa JI. Titi Kuning Namorambe Lingk. Vi Sidorejo Deli Tua Tahun 2014. Jurnal IImiah PANNMED (Pharmacist, Analyst, Nurse, Nutrition, Midwivery, Environment, Dentist), 9(2), 162165.

Tinanoff, N., \& Douglass, J. M. (2001). Clinical decision-making for caries management in primary teeth. Journal of Dental Education, 65(10), 1133-1142.

Twetman, S., Axelsson, S., Dahlgren, H., Holm, A., Källestål, C., Lagerlöf, F., Lingström, P., Mejàre, I., Nordenram, G., \& Norlund, A. (2003). Caries-preventive effect of fluoride toothpaste: a systematic review. Acta Odontologica Scandinavica, 61(6), 347-355.

Vinay, S., Naveen, N., \& Naganandini, N. (2011). Feeding and oral hygiene habits of children attending daycare centres in Bangalore and their caretakers oral health knowledge, attitude and practices. Indian Journal of Dental Research, 22(4), 561. 